\title{
TINGKAT KESIAPAN MASYARAKAT PENGELOLAAN LINGKUNGAN DAN KEPARIWISATAAN ALAM PASCA-ERUPSI 2010
}

\author{
Muhamad \\ Program Studi Kajian Pariwisata \\ Sekolah Pascasarjana Universitas Gadjah Mada \\ Email:drmuhammad@ugm.ac.id
}

\begin{abstract}
This study aims to assess and measure the level of community preparedness southern slopes of Merapi eruption after 2010. Readiness level of environmental management and nature based tourism to approach local potential values. The higher the level of community preparedness in managing the environment and natural tourism high semakain the readiness level of the index value.
\end{abstract}

Keywords: Community Preparedness, Environmentand Ecotourism

\begin{abstract}
ABSTRAK
Penelitian ini bertujuan untuk mengkaji dan mengukur tingkat kesiapan masyarakat lereng merapi selatan pascaerupsi 2010. Tingkat kesiapan pengelolaan lingkungan dan kepariwisataan alam didasarkan kepada pendekatan nilai-nilai potensi lokal.Semakin tinggi tingkat kesiapan masyarakat di dalam pengelolaan lingkungan dan kepariwisataan alam, maka semakain tinggi nilai indeks tingkat kesiapan tersebut.
\end{abstract}

Kata Kunci: Kesiapan Masyarakat, Lingkungan, dan Kepariwisataan Alam 


\section{PENGANTAR}

Secara kewilayahan, Kabupaten Sleman merupakan daerah yang paling terkena dampak bencana diperkirakan sekitar 65\% dari kerusakan dan kerugian dialami oleh Kabupaten Sleman disusul oleh Kabupaten Magelang yang menerima sekitar $15 \%$ dampak bencana, selanjutnya masing-masing 6\% dialami oleh Kabupaten Klaten dan Boyolali. Setelah erupsi Merapi 2010 desa-desa yang berada di wilayah Yogyakarta bagian utara mengalami berbagai gradasi lingkungan beserta daya tarik wisata serta potensi-potensi wilayahnya, sehingga menimbulkan dampak yang tidak sedikit. Pada artikel ini mencoba untuk menggali kembali potensi wilayah tersebut dengan pendampingan sebagai wujud kepedulian pemerintah untuk membantu kembali pemulihan sekaligus pemberdayaan masyarakat secara berkelanjutan.

Tahapan terpenting didalam siklus manajemen bencana pada pascabencana dengan cara mempercepat pemulihan wilayah dan masyarakat di dalamnya hingga mencapai kondisi sebagaimana sebelum terjadinya bencana. Setiap tahap pemulihan, maka diperlukan suatu proses pemulihan yang tepat, berdasarkan perencanaan yang baik, sehingga tepat sasaran serta mampu meningkatkan ketahanan masyarakat terhadap ancaman bencana di masa datang. Proses penanganan pascabencana yang baik harus menghasilkan pemulihan kondisi masyarakat, baik secara fisik, mental, sosial dan ekonomi, dan mampu menurunkan kerentanan terhadap bencana, bukan memperparah kondisi kerentanan yang ada yang menyebabkan terjadinya bencana (De Guzman, 2002).

Tulisan ini akan memberikan temuan tentang tingkat kesiapan masyarakat dalam pengelolaan lingkungan dan kepariwisataan alam di wilayah-wilayah perdesaan yang terkena bencana erupsi merapi 2010. Temuan ini diharapkan dapat digunakan untuk menentukan skala prioritas, selain juga menentukan sejumlah indikator kesiapan masyarakat.

Menurut Zanden, (1984) bahwa masyarakat sebagai satu kesatuan individu mempunyai pedoman dalam bersikap terhadap kegiatan. Salah satu yang mempengaruhi sikap tersebut adalah bagaimana melihat persepsi masyarakat yang berada di wilayah tersebut. Sikap dan persepsi masyarakat merupakan sebuah komponen kunci di dalam mengindentifikasi, pengukuran, dan analisis (Hasanah, 2004). Persepsi masyarakat terhadap pengaruh pariwisata tidak sama, tergantung bagaimana pengaruh pariwisata tersebut dipersepsikan. Persepsi yang berbeda akan menghasilkan sikap yang berbeda. Persepsi yang positif terhadap pengaruh kepariwisataan akan mengantarkan pada sikap positif terhadap kepariwisataan tersebut begitu juga sebaliknya.

Tingkat kesiapan masyarakat setelah mengalami erupsi tahun 2010 menghadapi berbagai pilihan-pilihan terpenting terutama berkaitan dengan pengelolaan lingkungan dan kepariwisataan alam beserta potensi lokal lainnya. Kesiapan masyarakat terhadap potensi lokal adalah kesiapan dalam usaha-usaha pengembalian (purification) penyediaaan jasa kepariwisataan alam. Tingkat kesiapan ini secara umum adalah proses seseorang untuk memahami lingkungan serta melibatkan pengorganisasian dan penafsiran sebagai rangsangan dalam pengalaman psikologis.

Masyarakat lokal sebagai satu kesatuan individu mempunyai pedoman dalam melakukan kesiapan terhadap lingkungannya, salah satu kesiapan tersebut antara lain persepsi masyarakat yang tinggal di wilayah tersebut. Kesiapan dan persepsi merupakan komponen kunci di dalam identifikasi, pengukuran, dan analisis (Hall dan Page, 1999). Kesiapan dan persepsi masyarakat tersebut tidak sama, tergantung bagaimana pengaruh sekitar lingkungannya tersebut dipersepsikan (Hasanah, 2004). Persepsi yang berbeda mengenai lingkungannya akan menghasilkan kesiapan yang berbeda terhadap lingkungannya tersebut. Persepsi yang positif terhadap pengaruh lingkungannya akan mengantarkan pada sikap positif.

Sikap positif tersebut dikemukakan Zanden (1984) bahwa dalam rangka adaptasi sosial, persepsi adalah jembatan yang 
menghubungkan antara manusia dan lingkungannya, baik lingkungan fisik maupun lingkungan sosial yang melibatkan pengorganisasian dan penafsiran. Pendapat tersebut didukung oleh Kartini dan Gulo dalam Hasanah (2004) yang menyatakan bahwa persepsi adalah proses ketika seseorang menjadi sadar akan segala sesuatu dalam lingkungan melalui indera yang dimilikinya, pengetahuan lingkungan melalui interpretasi.

Secara umum persepsi adalah proses seseorang untuk memahami lingkungan yang melibatkan pengorganisasian dan penafsiran sebagai rangsangan dalam pengalaman psikologis (Zanden, 2004). Sedangkan menurut Wells dan Prensky (1996) persepsi adalah suatu proses pengamatan, pengorganisasian, penginterpretasian, dan penilaian terhadap suatu obyek yang didasari oleh suatu pengetahuan yang dipengaruhi oleh faktor eksternal dan internal di dalam pengetahuan tersebut. Persepsi tingkat kepentingan wisatawan, dapat dirumuskan kepentingan yang paling dominan, sehingga diharapkan dengan memakai tingkat kepentingan ini dapat ditangkap persepsi yang lebih jelas mengenai pentingnya faktor-faktor tertentu di mata masyarakat dan wisatawan (Rangkuti, 2006).

Pencapaian pengetahuan manusia adalah untuk mengenali permasalahan, menganalisa, mengurai, menentukan interpretasi, dan menentukan pilihan-pilihan. Daya pengetahuan ini manusia mempertahankan dan mengembangkan hidup dan kehidupannya. Bersandar kepada daya, manusia membentuk sikap dan nilai hidup, menentukan pilihan- pilihan serta tindakan-tindakannya (Pranarka, 1987). Penentuan pilihan serta tindakan sikap sesorang ditentukan oleh pengetahuan yang diperolehnya. Seseorang akan bersikap positif apabila pengetahuan yang diperolehnya baik. Sebaiknya seseorang akan bersikap negatif apabila pengetahuan yang diperolehnya tidak sempurna.

Masslow (1984) menyebutkan bahwa sikap berisikan tiga aspek pokok, yaitu perasaan (afektif), aspek pikiran (kognitif), dan kecenderungan untuk bertindak (konatif). Bila sikap tidak dinyatakan dalam perilaku, maka sikap kehilangan makna. Dapat dikemukakan bahwa bagaimana perilaku masyarakat bergantung seberapa besar pengetahuan terhadap kepariwisataan dan sikap mereka terhadap lingkungannya.

Kesiapan merupakan sikap untuk berinteraksi terhadap sesuatu obyek dengan cara-cara tertentu atau kecenderungan potensial untuk berinteraksi apabila individu dihadapkan pada suatu stimulus yang menghendaki respon Rahkmat (1991). Goodwin (1997), Keraf (2000), dan Klun (1998) menjamin keikutan masyarakat setempat dan langkah-langkah yang perlu dicari agar masyarakat setempat dapat benar-benar terlibat dalam kegiatan pariwisata dengan beberapa pihak yang ikut terlibat, yaitu sektor pemerintah, swasta, dan masyarakat termasuk pelestarian dan pemanfaatan sumber daya alam secara lestari. Jaminan Goodwin (1997) tentang perlunya interaksi ketiga pihak yang ikut terlibat, yaitu sektor pemerintah, swasta, dan masyarakat setempat digambarkan pada gambar 1.1 di bawah ini.

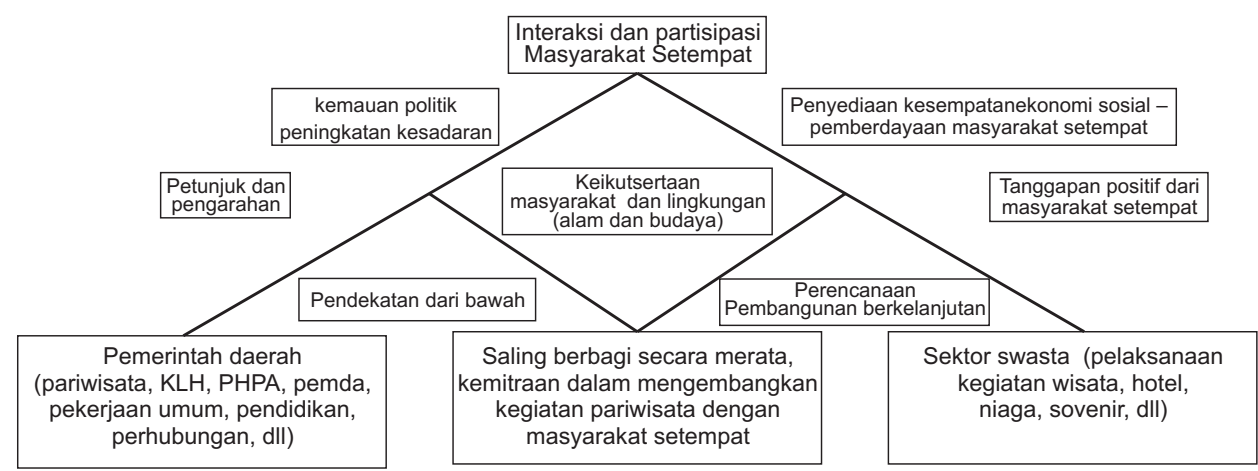

Keterlibatan para pihak terkait dalam kegiatan kepariwisataan antara: pemerintah, swasta dan Masyarakat setempat. Sumber: Godwin, (1997) 
Dari skema Goodwin (1997), keterlibatan para pihak terkait menurut aturan manajemen bersama (co-management) merefleksikan satu arti untuk mendapatkan pendekatan bersama, yaitu didesain untuk mengenal dan mempersatukan sistem pengetahuan lokal yaitu saling berbagi secara merata (kemitraan) dalam mengembangkan kegiatan pariwisata dengan masyarakat setempat, misalnya sektor swasta (pelaksanaan kegiatan wisata, hotel, niaga, souvenir, dan lain-lain). Sistem pengetahuan lokal tersebut menurut Pinkerton (1989) dan Ostron (1999) kondisi yang mendukung keberhasilan,yaitu interaksi, persepsi, dan keterlibatan masyarakat.

Berdasarkan uraian di atas, maka sistem pengetahuan lokal sangatlah berpengaruh terhadap persepsi masyarakat dan kebijakan pembangunan sehingga persepsi masyarakat merupakan adalah suatu proses penilaian masyarakat tentang segala sesuatu yang diakibatkan oleh adanya kegiatan pada skala tertentu. Pada akhirnya pengetahuan masyarakat diorganisasikan dan ditelaah dengan merujuk pada pengetahuan lokal dan interpretasi setiap individu masyarakat tentang performance suatu wilayah tentunya penginterpretasian fenomena yang dilihat dan dialami dari aktivitas sehubungan dengan pengaruh yang menguntungkan dan merugikan.

Kegiatan pariwisata memungkinkan terjadinya kontak antara wisatawan dari berbagai bagian dunia, berbagai bahasa, ras kepercayaan, paham politik, dan tingkat perekonomian dengan masyarakat sekitar objek wisata secara langsung maupun tidak langsung mengakibatkan pertukaran nilai sosial dan budaya.

Kontak antara beberapa komponen yang memungkinkan saling berinteraksi adalah hubungan antara lebih dari dua pihak dalam kepariwisataan terjadi antara masyarakat sekitar dan wisatawan dan objek daerah tujuan wisata. Masyarakat menurut Koentjaraningrat (1990) adalah kesatuan hidup manusia yang berinteraksi menurut suatu sistem adat istiadat tertentu yang bersifat kontinu yang terikat oleh suatu identitas.

Menurut Urry (1999), wisatawan berinterkasi dengan masyarakat lokal, yang melayani kebutuhan wisatawan (karyawan hotel, pemandu wisata, karyawan restoran, travel biro), dan masyarakat yang bukan pelaku industri pariwisata. Hubungan antara wisatawan dengan masyarakat bersifat sementara (transitory relationship) dan tidak berulang, ada kendala ruang dan waktu yang menghambat, bersifat transaksi ekonomi, interaksi umumnya bersifat unequal dan unbalanced (tidaksetara), dan pada umumnya masyarakat lokal merasa lebih inferior.

Keberhasilan pengembangan pariwisata akan berhasil jika melibatkan dan memberdayakan masyarakat, seperti dikemukakan oleh Smith (1996, dalam Soekamto, 2000) bahwa pemberdayaan masyarakat harus memperhatikan habitat, heritage, history, dan handicraft. Partisipasi masyarakat tidak hanya menerima aktivitas kepariwisataan di luar diri mereka, tetapi harus terlibat dalam pengembangan pariwisata.Selanjutnya keterlibatan tersebut menumbuhkan rasa memiliki dan memelihara kegiatan kepariwisataan. Pelibatan masyarakat menurut Cohen dan Uthoff (1979), harus memperhatikan tiga dimensi yaitu (1) bentuk partisipasi, (2) siapa yang berpartisipasi, dan(3) bagaimana partisipasi diimplementasikan.

Hasanah (2004) menyatakan bahwa masyarakat harus diikutsertakan dalam proses pembangunan pariwisata. Perbedaan kemampuan masyarakat dalam pengembangan pariwisata perlu diperhatikan agar terbentuk iklim yang kondusif bagi setiap pelaku pariwisata untuk berpartisipasi. Sosialisasi program merupakan kewajiban stakeholder pariwisata (terutama pemerintah) (Rodernberg (1980), tentu akan meningkatkan partisipasi karena masyarakat telah siap menerima dan beradapatasi (Inskeep (1986). Penerimaan masyarakat lokal ini akan mendorong usaha-usaha pariwisata berskala kecil dapat berkembang dan memiliki keunikan. 
Masyarakat sebagai penerima wisatawan dapat menerima kehadiran pengembangan suatu kawasan wisata jika mempunyai fungsi dan peranan dalam pengembangan kawasan wisata tersebut. Sikap dan pola penerimaan atau penolakan kehadiran pengembangan pariwisata dipengaruhi pendapat dan sikap tokoh masyarakat, seperti kepala desa, pemuka agama, guru, tokoh masyarakat, dan praktisi. Kesiapan masyarakat terhadap perubahan yang akan terjadi, dilihat dari sikap menerima atau menolak pembangunan pariwisata (Hasanah 2004).

Keterlibatan masyarakat dalam pengembangan pariwisata, ditentukan oleh beberapa faktor yang merupakan interaksi antara wisatawan dan masyarakat lokal sebagai berikut: pertama, kontras antara kekayaan di kawasan enclave dan keadaan di luarnya. Larangan bagi penduduk untuk ikut menggunakan sumber daya alam, seperti pemanfaatan rumput sebagai pakan ternak menimbulkan kecemburuan sosial. Kedua, ada golongan-golongan tertentu yaitu golongan yang mampu dan meniru tingkah laku mereka yang tidak cocok dengan kebudayaan masyarakat setempat. Kedua dampak di atas, dapat menimbulkan kesan yang negatif bagi masyarakat lokal. Di lain pihak, masyarakat lokal mempunyai pengetahuan yang lebih baik terhadap situasi lokal (termasuk budaya), maka wisatawan juga dapat menempati posisi inferior dan tereksploitasi.

Sebagaimana halnya hubungan manusia dari budaya yang berbeda, hubungan antara wisatawan dengan masyarakat lokal sangat dipengaruhi oleh sistem sosial budaya kedua belah pihak. Perbedaan sistem budaya ini tidak jarang menimbulkan konflik. Wisatawan, baik yang berasal dari mancanegara maupun yang datang dari pelosok-pelosok tanah air, memiliki latar belakang budaya yang beraneka ragam. Semua itu akan berpengaruh besar terhadap kebudayaan masyarakat tempat tujuan wisata tersebut.

Interaksi sosial antara wisatawan dengan masyarakat setempat di daerah pariwisata tersebut akan menimbulkan masalah-masalah sosial baru yang tidak terbatas pada pola-pola interaksi sosial di antara mereka yang terlibat saja, tetapi mempengaruhi sistem nilai budaya setempat serta timbulnya nilai sosial baru termasuk pengetahuan (Hasanah, 2004). Pengetahuan berfungsi untuk mengenali, menganalisa, mengurai, interpretasi suatu permasalahan, dan menentukan pilihanpilihan solusinya. Seseorang bersikap positif apabila pengetahuan benar dan sebaliknya bersikap negatif apabila pengetahuan yang diperolehnya tidak sempurna. Menurut Rakhmat (1991), sikap seseorang menjadi bermakna jika dimplementasikan dalam perilaku.

\section{PEMBAHASAN}

Pola pengembangan desa wisata di Yogyakarta utara (kabupaten Sleman) dilakukan berdasarkan unsur-unsur yang ada di wilayah desa tersebut. Penentuan desa wisata harus diimbangi dengan pemahaman terhadap karakteristik serta tatanan sosial budaya masyarakat. Hal ini dimaksudkan untuk dapat dimanfaatkan dalam pengembangan aspek pengelolaan lingkungan dan kepariwisataan di desa tersebut. Pada aspek yang lain yang perlu dilakukan untuk dapat menentukan jenis dan tingkatan pemberdayaan masyarakat secara tepat guna berhasil guna dan menemu kenali tingkatan penerimaan/kesediaan masyarakat terhadap kegiatan pariwisata. Pada pengembangan desa wisata di wilayah Yogyakarta Utara, prinsip-prinsi yang harus dilakukan sebagai berikut: Pertama, tidak bertentangan dengan adatistiadat atau budaya masyarakat setempat. Pengembangan desa wisata harus memperhatikan berbagai aspek yang berkaitan dengan kehidupan sosial budaya dan mata pencaharian desa tersebut; Kedua, pembangunan fisik dan sarana prasarana ditujukan untuk meningkatkan kualitas lingkungan desa. Pengembangan pariwisata suatu desa pada hakikatnya tidak merubah. apa yang sudah ada di desa tersebut, tetapi 
ada tujuan untuk mengemas sedemikian rupa sehingga menarik untuk dijadikan atraksi wisata; Ketiga, memperhatikan unsur kelokalan dan keaslian; Keempat, memberdayakan masyarakat. Unsur penting dalam pengembangan desa wisata adalah keterlibatan masyarakat desa dalam setiap aspek wisata yang ada di desa tersebut; Kelima, memperhatikan daya dukung dan daya tampung serta berwawasan lingkungan.

Pengembangan desa menjadi desa wisata harus memperhatikan kapasitas tersebut, baik kapasitas fisik maupun kesiapan masyarakat. Prinsip-prinsip pariwisata yang berkelanjutan (sustainable development) harus mendasari pengembangan desa wisata. Kabupaten Sleman di wilayah bagian Utara banyak memiliki potensi-potensi desa wisata untuk dikembangkan. Secara geografis wilayah lereng bagian tengah (Kecamatan Pakem) merupakan wilayah perbukitan dan pegunungan dengan ketinggian antara 450 meter hingga $2000 \mathrm{mdpl}$. Lereng tersebut ke utara semakin terjal dengan kemiringan antara 35\% sampai dengan $45 \%$. Sebagian besar masyarakat lereng Gunung Merapi bagian tengah berprofesi sebagai petani dan pekebun. Wilayah ini dibagi dalam dua wilayah sesuai dengan topografi dan ketersediaan air tanah, yaitu wilayah utara dan wilayah selatan.

Desa wisata Sambi adalah merupakan salah satu diantara 27 Desa Wisata yang berada di Kabupaten Sleman Propinsi Daerah Istimewa Yogyakarta, dan tepatnya di Jalan Kaliurang Km 19,7 Padukuhan Sambi Desa Pakembinangun Kecamatan Pakem Kabupaten Sleman. Sebelum terbentuknya Desa Wisata Dusun Sambi, sebenarnya Padukutan Sambi telah banyak para wisatawan mancanegara yang senang berkunjung dan bertempat tinggal di Dusun Sambi tersebut. Para wisatawan mancanegara berdatangan dari beberapa negara seperti Australia, Belanda, Canada, dan Jerman. Pada saat itu mereka senang mengadakan berbagai pertemuan, makan bersama, rapat kerja, dan lain-lain.

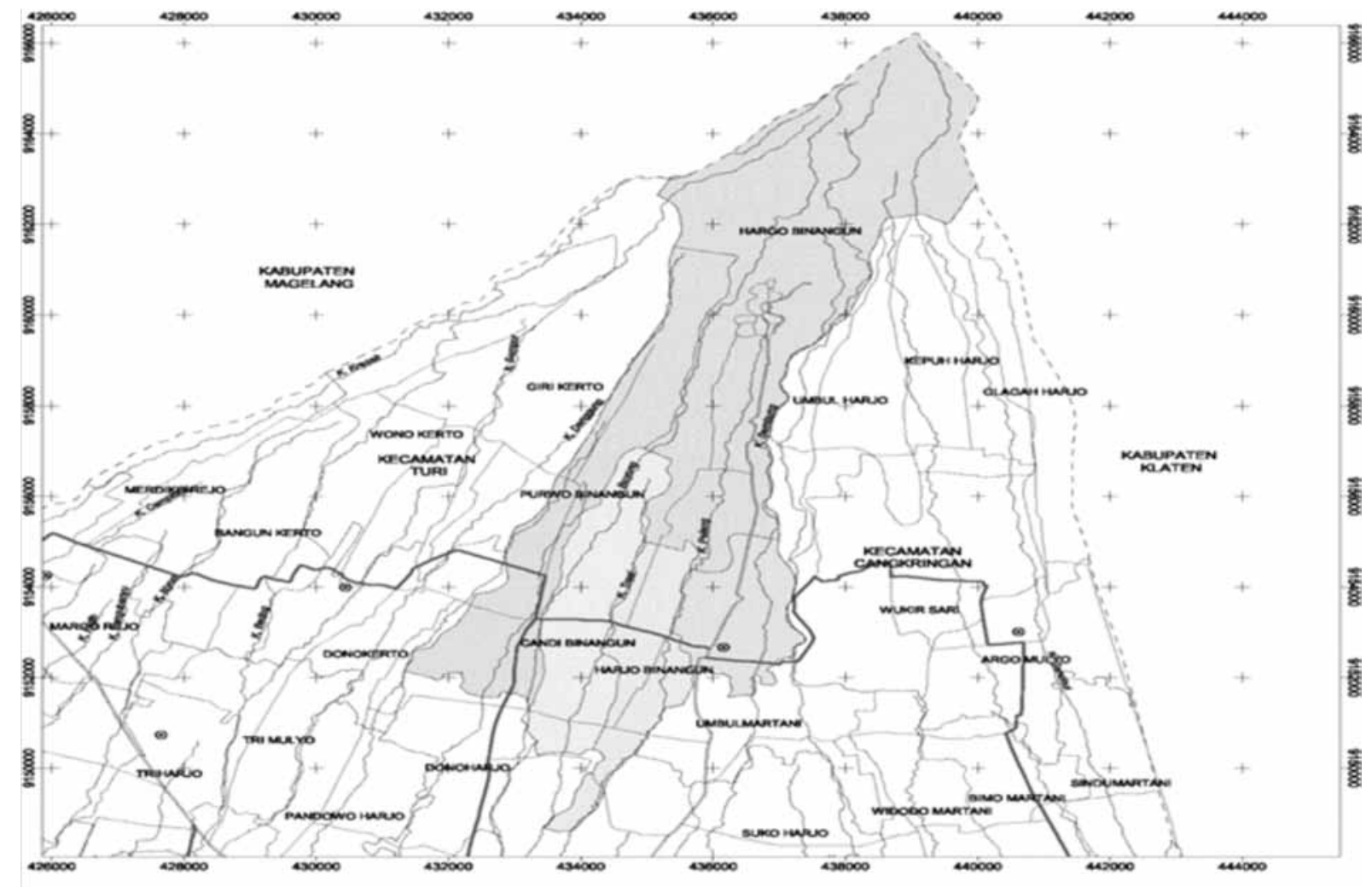

Gambar 1 Peta Administrasi Lereng Selatan Merapi

Sumber: Bapeda Kabupaten Sleman di modifikasi, 2011 
Panorama keindahan alam, bentang alam, dan karakteristik sumber daya wisata yang terdapat di kawasan lereng Gunung Merapi bagian tengah merupakan sudut pandang dan titik tangkap untuk melihat keelokan Gunung Merapi, seperti pada gambar di bawah ini.
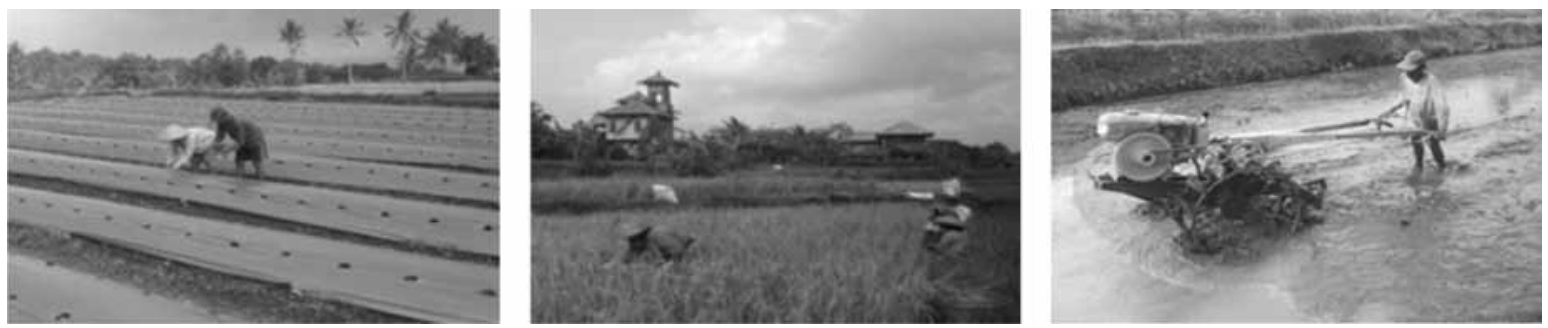

Gambar 2 Panorama Alam di Desa Wisata

Sumber: Dokumen Pribadi, 2011

Tabel 1

Karakteristik Sumberdaya Wisata Kecamatan Pakem

\begin{tabular}{|c|c|c|}
\hline No & \begin{tabular}{|c|} 
Obyek dan Daya \\
Tarik Wisata \\
\end{tabular} & Karakteristik Sumberdaya Wisata \\
\hline 1 & $\begin{array}{l}\text { Sebelah utara } \\
\text { Dusun Tanen } \\
\text { (Gerbang Lama), } \\
\text { Hargobinangun, }\end{array}$ & $\begin{array}{l}\text { - Daya tarik mempunyai pemandangan ke Merapi cukup jelas. } \\
\text { - Parkir luas dan tersedia tempat pengamatan langsung Gunung Merapi. } \\
\text { - Daya dukung apabila aktivitas Merapi membahayakan, pengunjung } \\
\text { dapat segera meninggalkan lokasi karena tersedia jalur evakuasi }\end{array}$ \\
\hline 2 & $\begin{array}{l}\text { Pandanpuro } \\
\text { (dekat rencana } \\
\text { Taman Bunga) } \\
\text { Hargobinangun, }\end{array}$ & $\begin{array}{l}\text { - Daya tarik merupakan pemandangan ke puncak Merapi cukup jelas } \\
\text { - Fasilita tersedia lokasi pengamatan langsung ke Merapi. } \\
\text { - Daya dukung apabila aktivitas merapi membahayakan, pengunjung } \\
\text { dapat segera meninggalkan lokasi karena tersedia jalur evakuasi }\end{array}$ \\
\hline 3 & $\begin{array}{l}\text { Dusun Sambi, } \\
\text { Pakembinangun, } \\
\text { Pakem }\end{array}$ & $\begin{array}{l}\text { - Daya tarik mempunyai view ke Merapi cukup jelas, merupakan } \\
\text { wilayah Desa Wisata Sambi dengan nuansa pedesaan, kehidupan } \\
\text { pertanian dan lingkungan pemukiman yang bersih. } \\
\text { - Fasilitas homestay, hotel dan penginapan. } \\
\text { - Daya dukung apabila aktivitas merapi membahayakan, pengunjung } \\
\text { dapat segera meninggalkan lokasi karena tersedia jalur evakuasi }\end{array}$ \\
\hline 4 & $\begin{array}{l}\text { Sebelah Selatan } \\
\text { RS Grasia Pakem, } \\
\text { Pakembinangun, } \\
\text { Pakem }\end{array}$ & $\begin{array}{l}\text { - Daya tarik mempunyai view ke Gunung Merapi cukup jelas. } \\
\text { - Fasilitas tersedia lokasi pengamatan langsung ke Gunung Merapi. } \\
\text { - Daya dukung apabila aktivitas merapi membahayakan, pengunjung } \\
\text { dapat segera meninggalkan lokasi karena tersedia jalur evakuasi. }\end{array}$ \\
\hline
\end{tabular}

Sumber: Pengamatan Lapangan, 2011

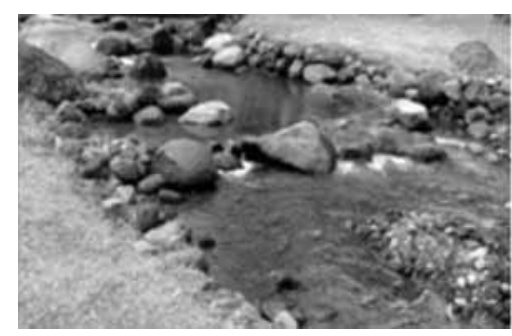

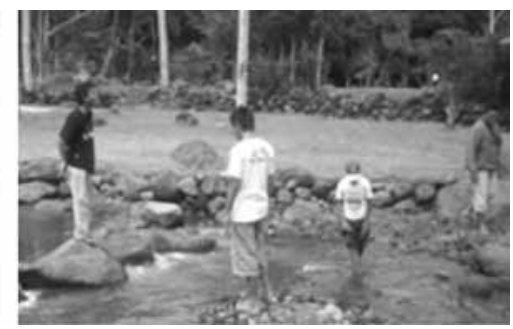

Gambar 3

Pemanfatan Alam untuk Wisata Alam di Dusun Sambi dengan Pemandangan Sungai

Sumber: Dokumen Pribadi, 2011 


\section{Pengelolaan Lingkungan dan Kepariwisataan Alam Pasca- Erupsi 2010}

Pengelolaan lingkungan dan kepariwisataan alam di Yogyakarta bagian utara pasca erupsi 2010 merupakan performance persepsi sosial masyarakat di dalam menyikapi kondisi tersebut. Performa dihasilkan oleh sikap sesorang yang ditentukan oleh pengetahuan yang dimilikinya. Seseorang akan bersikap positif apabila pengetahuan yang dimilikinya baik, sebaiknya seseorang akan bersikap negatif apabila pengetahuan yang diperolehnya tidak sempurna.

Sikap mengandung tiga aspek pokok, yaitu perasaan (afektif), aspek pikiran (kognitif) dan kecenderungan untuk bertindak (konatif). Sebagai alat analisis model IPA (Importance Performance Analysis), diimplementasikan sebagai alat untuk mengembangkan dan membangun strategi yang mengombinasikan atribut-atribut persepsi kepentingan masyarakat dalam bentuk skala Likert. Analisis ini digunakan para peneliti. Kesiapan masyarakat beserta tingkat kepentingan dalam kajian ini diukur dalam kaitannya dengan apa yang telah dilakukan oleh masyarakat lokal sebagai penyedia jasa agar menghasilkan produk jasa berupa lingkungan dan kepariwisataan yang berkualitas tinggi. Tingkat kepentingan didalam kajian ini dipergunakan untuk merumuskan bentuk performa yang lebih jelas mengenai pentingnya variabel-variabel penelitian yang kemudian dibandingkan dengan pencapaian yang diperoleh di empat kuadran yang memuat beberapa faktor.

Kesiapan masyarakat beserta tingkat kepentingan dalam penelitian ini diukur melalui empat kuadran yang akan diinterpretasikan masing-masing dapat dijelaskan sebagai berikut:

a. Kuadran I: wilayah yang memuat faktor-faktor yang dianggap penting bagi oleh masyarakat lokal, tetapi pada kenyataannya faktor-faktor ini belum sesuai seperti yang diharapkan (tingkat kepuasan dari wisatawan masih rendah).

b. Kuadran II: Wilayah yang memuat faktorfaktor yang dianggap penting bagi oleh masyarakat lokal, faktor-faktor ini sudah sesuai seperti yang diharapkan. Variabelvariabel yang terdapat dikuadran ini harus dipertahankan.

c. Kuadran III: Wilayah yang memuat faktor-faktor yang dianggap kurang penting oleh masyarakat lokal dan pada kenyataannya kinerjanya tidak terlalu istimewa.

d. Kuadran IV : Wilayah yang memuat faktor-faktor yang dianggap kurang penting bagi oleh masyarakat lokal dan dirasakan terlalu berlebihan.

Analisis untuk mengukur tingkat kesiapan dan persepsi masyarakat terhadap pengelolaan lingkungan dan kepariwisataan alam menggunakan metode Importance and Performance Analysis (IPA). Kesiapan tersebut dilakukan dengan mengolah data angket tentang keterkaitan antara tingkat kepentingan suatu objek/layanan yang diinginkan, menurut persepsi masyarakat lokal.

Analisis data diperoleh dengan memberikan daftar pertanyaaan yang berisi 13 hal yang dirasa penting kepada 50 responden, yaitu masyarakat di Kecamatan Pakembinangun Merapi lereng selatan. Bagian pertama pertanyaan itu untuk mengukur tingkat kepentingan suatu variabel menurut persepsi responden (masyarakat lokal) dan 13 pertanyaan lainnya untuk mengetahui seberapa besar tingkat pencapaian yang ada sebagai instrumen untuk mengukur tingkat kesiapan masyarakat atas keinginan yang sudah dituangkan pada bagian pertama kuesioner ini.

Data yang diperoleh dari responden melalui kuisioner tentang tingkat kesiapan dan kepuasan masyarakat, kemudian dihitung nilai reratanya untuk setiap variabel dan hasilnya ditampilkan pada tabel 1.1 berikut ini: 
Tabel 2

Nilai Rerata Skor Setiap Variabel Tingkat KesiapanMasyarakat Lokal

\begin{tabular}{l|l|l|l}
\hline No & Variabel Tingkat Kesiapan masyarakat lokal & Kesiapan & Kepuasan \\
\hline 1 & Sarana dan prasarana fisik penunjang kepariwisataan & 3.21 & 3.74 \\
\hline 2 & Manajemen organisasi pengelolaan objek daya tarik wisata & 2.63 & 3.15 \\
\hline 4 & Kualitas pelayanan wisata & 2.78 & 3.71 \\
\hline 5 & Kven dan kegiatan wisata & 2.25 & 2.67 \\
\hline 6 & Pelestarian budaya masyarakat (budaya vulkanologis) & 2.82 & 2.84 \\
\hline 7 & Tingkat kesadaran wisatawan terhadap objek wisata & 2.73 & 3.61 \\
\hline 8 & Peran stakeholder & 2.29 & 3.54 \\
\hline 9 & Peningkatan pendapatan masyarakat sekitar & 2.41 & 3.85 \\
\hline 10 & Informasi wisata (website, internet/humas) & 2.67 & 3.69 \\
\hline 12 & Kepariwisataan sebagai pendidikan & 2.89 & 3.53 \\
\hline 13 & Pelestarian ligkungan kepariwisataan & 3.05 & 3.57 \\
\hline
\end{tabular}

Sumber : Survei diolah, 2011

Strategi yang dapat dilakukan berkenan keempat kuadran tersebut dapat dijelaskan dengan posisi masing-masing variabel pada sebagai berikut.

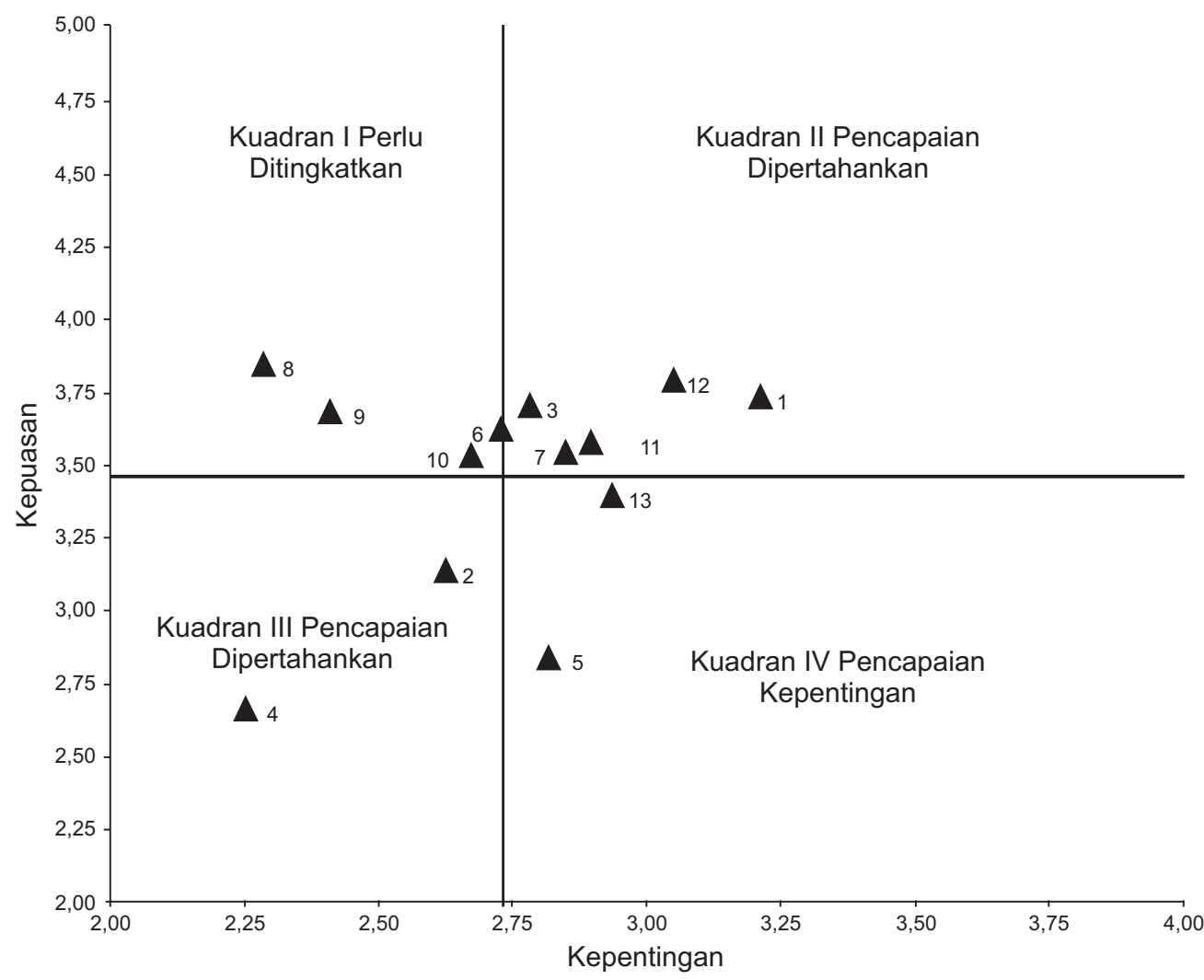

Gambar 4

Diagram Kartesian Tingkat Kepentingan (importance) Versus Tingkat Pencapaian (performance) Kegiatan Pariwisata di Yogyakarta Bagian Utara

Sumber (Analisis peneliti, 2011) 


\section{Variabel Tingkat Kesiapan Masyarakat dalam Pengelolaan Lingkungan dan Kepariwisataan Alam pada Kuadran I}

Variabel tingkat kesiapanmasyarakat dan pencapaian pada kuadran I terdiri dari: $\left(\mathrm{V}_{6}\right.$, pelestarian budaya) mempunyaitingkat kesiapan dan tingkat kepuasan dengan rerata (2.73 dan 3,61), ( $\mathrm{V}_{8^{\prime}}$ peran para stakeholder) mempunyai tingkat kesiapan dan kepuasan $(2,29$ dan 3,85$),\left(V_{9}\right.$, peningkatan pendapatan masyarakat sekitar) dengan tingkat kesiapan dan kepuasan $\left(2,41\right.$ dan 3,69), $\left(\mathrm{V}_{10}\right)$, informasi kepariwisataan (website, internet/humas) dengan tingkat kesiapan dan kepuasan $(2,67$ dan 3,35).

Berdasarkan hasil analisis diatas faktor tingkat kesiapan masyarakat pada kuadran I dianggap penting oleh masyarakat. Akan tetapi,tingkat kepuasan masyarakat terhadap capaian variabel-variabel tersebut masih rendah. Sehingga pencapaian ke 4 variabel tersebut harus ditingkatkan.

Variabel pelestarian budaya $\left(\mathrm{V}_{6}\right)$ dan variabel informasi wisata $\left(\mathrm{V}_{10}\right)$ meskipun secara numerikskornya kurang dari rerata,tetapi posisinya pada diagram berimpit dengan kedua garis rerata sehingga performanya dianggap mendekati apa yang diinginkan oleh masyarakat.

Variabel kesiapan masyarakat dan menurut persepsi masyarakat mempunyai nilai penting (nilai tingkat kepentingannya tinggi di atas rata-rata $=3.47$ ), tetapi performance tidak seperti yang diharapkan masyarakat (nilainya kepuasannya kurang dari rata-rata kepuasan berkisar 2,73 (Tabel 1.1), sehingga variabel kuadran ini harus melakukan perbaikan secara terus menerus sehingga performance kesiapan masyarakat akan meningkat.

\section{Tingkat Kesiapan Masyarakat pada Kuadran II}

Variabel tingkat kesiapan masyarakat yang terdapat pada kuadran II merupakan faktor-faktor yang terdiri dari $\left(\mathrm{V}_{3}\right)$, kualitas pelayanan wisatadengan tingkat kesiapan dan kepuasan mempunyai rerata $(2,78$ dan $3,71),\left(V_{7}\right)$ tingkat kesadaran terhadap objek wisata dengan tingkat kesiapan dan kepuasan (2,85 dan 3,54), $\left(\mathrm{V}_{11}\right)$, kepariwisataan sebagai pendidikan dengan tingkat kesiapan dan kepuasan $(2,89$ dan 3,57$),\left(V_{12}\right)$, pelestarian lingkungan kepariwisataan dengan tingkat kesiapan dan kepuasan (3,05 dan 3,80), $\left(\mathrm{V}_{1}\right)$ Sarana dan prasarana fisik penunjang kepariwisataan dengan tingkat kesiapan dan kepuasan 3,21 dan 3,74.

Hasil analisis menunjukan bahwa variabel yang terletak dikuadran II harus tetap dipertahankan dan ditingkatkan secara berkesinambungan sehingga tetap bisa memenuhi tuntutan masyarakat. Variabelvariabelpadakuadraninitingkatkesiapannya dianggap tinggi terutama $\left(\mathrm{V}_{12}=3,21\right)$ dan $\left(\mathrm{V}_{1}=3,74\right)$ oleh masyarakatsehingga harus tetap dipertahankan karena semua variabel ini menjadikan desa wisata tersebut menjadi sutu keunggulan. Secara numerikskor ratarata tinggidan posisinya pada diagram berimpit dengan kedua garis rerata sehingga performanya dianggap mendekati apa yang diinginkan oleh masyarakat.

\section{Tingkat Kesiapan dan Pencapaian pada Kuadran III}

Variabel tingkat kesiapan variabel yang terdapat pada kuadran III terdiri dari: $\left(\mathrm{V}_{2}\right)$, manajemen organisasi pengelolaan objek dan daya tarik wisata dengan tingkat kesiapan mempunyai rerata 2.63 dan $3.15,\left(\mathrm{~V}_{4}\right)$ kegiatan dan event kepariwisataan dengan tingkat kesiapan 2.25 dan 267 dikelompokkan dalam kuadran III. Variabel pada kuadran ini merupakan variabel yang menurut persepsi masyarakat tidak penting, sehingga variabel $\left(\mathrm{V}_{2}\right)$ peningkatan pendapatan masyarakat sekitar dan $\left(\mathrm{V}_{4}\right)$ event atau kegiatan kepariwisataan tidak begitu dipentingkan oleh masyarakat di wilayah Yogyakarta bagian utara.

Peningkatan nilai rerata pada variabel-variabel yang masuk kuadran ini dapat dipertimbangkan kembali karena pengaruhnya terhadap manfaat yang dirasakan kecil. Penggambaran secara visual pada grafik kartesian $\left(\mathrm{V}_{2}\right)$ terletak berimpit dengan nilai rata-rata sehingga tingkat 
kepuasan masyarakat atau capain prestasi mempunyai hasil yang tidak terlalu tinggi dibandingkan tingkat kepentingannya.

\section{Tingkat Kesiapan dan Pencapaian pada Kuadran IV}

Variabel tingkat kesiapan masyarakat variabel yang terdapat pada kuadran $\operatorname{IVyaitu}\left(\mathrm{V}_{5}\right)$ kualitas sumberdaya pariwisata mempunyai rerata numerik 2.84 dan 2.82, variabel $\left(\mathrm{V}_{13}\right)$ variabel modifikasi lingkungan alam pencapaian/prestasi yang diperoleh berada mendekati dan berimpit. Kualitas sumber daya pariwisata dan modifikasi lingkungan alam kedua variabel ini perlu ditingkatkan karena sumber daya pariwisata dan modifikasi lingkungan alam dianggap penting, tetapi pada kenyataanya tidak ada di lapangan, pencapaiannya numerik kuadran IV rata-rata rendah, dengan kata lain masyarakat merasa keinginnya belum dipenuhi.

\section{SIMPULAN}

Tingkat kesiapan masyarakat lokal disuatu wilayah yang terkena kebijakan secara umum melibatkan pengorganisasian dan penafsiran sebagai rangsangan dalam pengalaman yang menghasilkan beberapa variabel tingkat kesiapandan kepuasan. Tingkat kesiapan masyarakat tersebut didasarkan kepada pendekatan nilai-nilai potensi lokal yang terdapat di wilayah tersebut melalui proses pengamatan, pengorganisasian, penginterpretasian dan penilaian terhadap suatu obyek yang didasari oleh suatu kesan dan pemikiran serta pengetahuan, yang dipengaruhi oleh faktor eksternal dan internal di dalam pemanfaatan sumber daya.

Temuan pencapaian yang sesuai dengan kesiapan masyarakat lokal, yaitu kualitas pelayanan wisata, tingkat kesadaran masyarakat terhadap objek wisata, wisata sebagai pendidikan, pelestarian lingkungan, dan sarana serta prasarana fisik penunjang pariwisata.

Variabel tingkat kesiapan masyarakat di dalam pengelolaan lingkungan dan kepariwisataan alam di Yogyakarta bagian utara pasca-erupsi 2010mempunyai nilai ratarata dengan indeks yang tinggi meskipun tingkat kepuasan masyarakat terhadap capaian variabel-variabel tersebut masih perlu ditingkatkan,yaitu dianggap mendekati apa yang diinginkan oleh masyarakat sekitar.

\section{DAFTAR PUSTAKA}

Azwar. S. 1997. Reliabilitas dan validitas (Edisi ke 3). Pustaka Pelajar. Yogyakarta.

Beckman. S. 2004. "Mencari Keseimbangan Pengelolaan Interaksi Antara Masyarakat dan Kawasan Taman Nasional Alas Purwo Laporan studi lapangan". Fakultas Ilmu Sosial Ilmu Politik Universitas Muhammadiyah. Malang.

Colinvaux. P. 1986. Ecology. John Wiley dan Sons. New York.

Cook. R.S. Jr. 1984. Zone for Down Town Urban Design. How Cities Control Development. Lexington Books.

Cooper. C. Fletcher. J. Gillbert.D dan Stephen W. (1993). Tourism. Principles dan Practice. London. Pitman Publishing.

Crompton. J.L. 1979. “An Asseesment of the Mexico as a vacation Destination dan The influence of Geographical Location Upon that image" dalam Journal of Travel Research 17(4) hal 32-38.

Dajan. A. 2000. Pengantar Metode Statistik. Jakarta LP3ES.

Danrew. H. 2001. Environment dan Tourism. Rontledge Introduction to Enviroment Series. USA.

Dauglas. RW. 1975. Forest Recreations. Second Edition .Pergamon Press Inc. New York.

Doxey. J.P. 1975. A Causation Theory of VisitorResident Irritants. Metodology. and Research Inverences. The Impact of Tourism. Travel Research \& Association.

Ergun. Goleman and Peter. R. Stopher. 1981. The Effect of Personality on Demand for Recreation Activities. Some Preliminery Findings. London. pergamon Press. 
Goodwin H. 1997. Terestrial Ecotorism. Planning SustainableTourism. Penerbit ITB. Bandung.

Gunn. C.A. 1994. Tourisme Planning Bassic. Concept. Casees London: Taylor dan Francis Ltd.

Hall. C.M. dan Page. S.J. 1999. The Geography of Tourism and Recreation Environment. Place dan Space. New York. Routledge.

Hasanah. N. 2004. “Hubungan Antara Persepsi Dampak Pariwisata Budaya. Tipe Nilai Universal. Tipe Nilai Tradisi. Nilai Tradisi. dan Tipe Nilai Keamanan dengan Sikap Pariwisata Budaya". Tesis (tidak diterbitkan). Jurusan IlmuIlmu Sosial. Program Studi Psikologi Sekolah Pascasarjana. Universitas Gadjah Mada. Yogyakarta.

Inskeep. E. 1991. Tourism Planning an Intergrated and Sustainable Development Approach, New York: Van Nostrand Reinhold.

Intosh. Mc. R. dan Geoldner. C.1984. Tourism Principles. Practices. Philosophies. Ohio. Gris Publishing.

Kadt. D.E. 1979. “Social Planning for Tourism in the Development Countries". Annuals of Tourism Research 6 (1) pp 36-68. Oxford University Press for World Bank dan Unesco.

Keraf. A.S.2002. Etika Lingkungan. Penerbit Buku Kompas. Jakarta.

Klun H. 1998. Promotion of Sustainable Management. du Grey Switzerldan.

Koentjaraningrat. 1996. Pengantar Antropologi I. Jakarta : Rineka Cipta.

Kusmayadi dan Sugiarto E. 2000. Metodologi Penelitian dalam Bidang Kepariwisataan. PT Gramedia Pustakan Utama. Jakarta.

Maryani. E. 2004. "Struktur Keruangan Pariwisata di Kawasan Inti Bandung Raya". Disertasi. Program Pascasarjana Universitas Gadjah Mada. (tidak diterbitkan) Yogyakarta.

Masslow.A.H.1984.Motivationand Personallity. Harper and Row. London.
Mathieson A. and Wall. G. 1982. Tourism. Economic. Physical and Social Impacts. Longman Singapore Ltd. Singapura. Mc Graw Hill Company. Inc. New York. Toronto. London.

Mill. R.C. dan A. M. Morrison. 1985. The Tourism System. An Introductory Text. Englewood Clifft. New Jersey.

Muhamad. 2010. Kepariwisataan Berkelanjutan di Wilayah Yogyakarta Utara, Disertasi Magister Kajian Pariwisata, tidak dipublikasikan, Yogyakarta.

Pearce. D.G. 1998. Tourism Development . John Willey \& Sons Inc. New York.

Pizam A. Newman Y. dan Reichel A. 1979. "Tourism Satisfaction: Uses dan Messages" dalamAnalysis of Tourism Research6(2) . hal 196-5.

Plog. S.C. 1972. Why Destination Areas Rise dan Fall in Popularity. Travel Research Association.

Pranarka. A.M.W.1987. Epistemologi Dasar Suatu Pengantar. Center for Strategic and International Studies (CSIS), Jakarta.

Rakhmat. J. 1991. Psikologi Komunikasi. PT Remaja Rosdakarya. Bandung.

Rangkuti. F. 2006. Measuring Customer Satisfaction. Gramedia Pustaka Utama. Jakarta.

Smith. S.J. 1983. Recreation Geography. London.Longman.

Soemarwoto. O. 1998. Ekologi Lingkungan Hidup dan Pembangunan. Djambatan.. Jakarta.

Veal. A.J. 1992. Research Methode for Leisure dan Tourism. Institute of Leisure.

Wells. W.D dan Prensky. D. 1996. Consumer Behavior. New York: John Wiley and Sons, Inc.

Zanden, Z.W.1984. Social Psychologi. New York: Random House.

Ziffer K.A. 1989. Eco-tourism: The Uneasy Alliance.Conservation International. 